SII StUdIA MARITIMA | XXXIV (2021) | 61-86 | ISSN (print): 0137-3587 | ISSN (online): 2353-303X | D0I: 10.18276/sm.2021.34-03

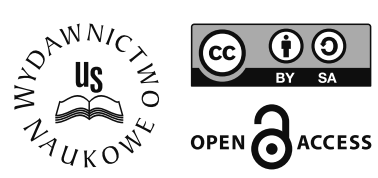

\title{
Krystyna Szelągowska
}

Faculty of History and International Relations

University of Bialystok

k.szelagowska@uwb.edu.pl

ORCID: 0000-0002-5195-044X

\section{Casting a glance across Balticum - Poland and her past in Arild Huitfeldt's Chronicle $^{1}$}

Keywords: Arild Huitfeldt, Renaissance historiography, Baltic region

\section{Introduction}

To study the way how other nations perceived our own country has always been an interesting and significant topic for historians. Depending on the period, this may be a question of opinions among intellectual and political elites or wider masses of the population. An obvious motive for this interest is simple curiosity, produced by the desire "not to be forgotten". More serious could be the need to obtain information which could help explain some aspects of the past, such as political decisions. They can be clarified, their rationale can be shown if we realise what the decision-makers knew about the country, with which they were dealing. It was important to learn, what facts were known, what cliches were circulating among the educated, what experiences of previous contact were preserved and remembered.

Another purpose can be pointed out in the situation when a foreign description delivers a picture in some ways different to the one, common in the national memory,

1 This work was supported by a grant from National Science Centre, Poland, no. 2018/29/B/HS3/01023. A brief outline of this paper was presented on the conference in October 2019, in Gdańsk, organised by Polsk-Skandinavisk Forskningsinstitut and the University of Gdańsk and is published in: Polsko-skandynawskie stosunki kulturalne, naukowe i polityczne od XVI do XX wieku, eds. Arnold Kłonczyński, Gabriela Majewska (Gdańsk: Wydawnictwo Uniwersytetu Gdańskiego, 2021), $29-45$. 
presenting it from another perspective. The confrontation of those two can expose weaknesses or bias in both ${ }^{2}$.

If we focus on historical works, we can see what information was seen as important and worth commemorating - included in the sources, both primary and secondary. Writing his own vision of history, the scholar, willingly or not, consciously or not, had to select pieces of information, using those he found important and/or interesting. If we study the sources used, we can follow the flow of the information.

There were several Polish students of the Early Modern era, interested in the topic, among whom we can name Stanisław Kot, Zofia Libiszowska, Andrzej F. Grabski, Henryk Zins, we can also list collections of works of more detailed character ${ }^{3}$. In most cases it was the public opinion in such countries like England, France, the German Reich or Hapsburg domains which were under scrutiny in these works. The Scandinavian countries were the object of study usually in context of bilateral relations, obviously it meant focusing on Swedish writing.

An old, but still useful and valuable, work on Polish-Scandinavian cultural relations by Kazimierz Ślaski provides us with a multitude of, although scattered, notes and remarks about Poland in Scandinavian (and vice versa) works: both scholar and literary ${ }^{4}$. Works on the history of Pomerania very often use and refer to Danish sources.

When studying any foreigner's opinion on one's country, as was mentioned above, an ambitious program could be drawn, and its fulfilment could fruitfully be exploited to enlarge the picture of this country's past. Unfortunately, this can not always be done. In Early Modern times' historical books, based in most cases on repetition, compilation and imitation, attempting to realise the programme of utilitarian historiography and, finally, usually following the principle of authority, i.e., the paradigm of non-critical history, the information was included in most cases by pure coincidence. Simply because it was found somewhere and the historian automatically repeated it ${ }^{5}$.

2 Andrzej Garlicki, "Przedmowa”, in: Sąsiedzi i inni, ed. A. Garlicki (Warszawa: Czytelnik, 1978), 5.

3 Zofia Libiszowska, "Zainteresowanie Polską w historiografii francuskiej XVI i XVII wieku”, Zeszyty Naukowe Uniwersytetu Łódzkiego, Nauki Humanistyczno-Społeczne, 1 (1959), 12: 63-82; Stanisław Kot, Rzeczpospolita Polska w literaturze politycznej Zachodu (Kraków: Krakowska Spółka Wydawnicza, 1919); Andrzej F. Grabski, Polska w opiniach obcych X-XIII wiek (Warszawa: PWN, 1964); idem Polska w opiniach Europy Zachodniej XIV-XV wiek (Warszawa: PWN, 1968); Henryk Zins, Polska w oczach Anglików (Warszawa: PIW, 1974); the collection Sasiedzi i inni has been mentioned above, a recent one would be Mirosława Hanusiewicz-Lavallee, ed. Wśród krajów Północy. Kultura Pierwszej Rzeczypospolitej wobec narodów germańskich, słowiańskich i naddunajskich: mapa spotkań, przestrzenie dialogu (Warszawa: Wydawnictwo Uniwersytetu Warszawskiego, 2015).

4 Kazimierz Ślaski, Tysiąclecie polsko-skandynawskich stosunków kulturalnych (Wrocław: Zakład Narodowy im. Ossolińskch, 1977), 61, 70, 141-142.

5 Peter Burke, Renesans, transl. Ewa Elżbieta Nowakowska (Kraków: Wydawnictwa UJ, 2009), 6; Dariusz Śnieżko, "Jak Marcin Bielski przerabiał z dobrego na lepsze", in: Tożsamość i rozdwojenie. Renesans, ed. L. Wiśniewska (Bydgoszcz: Akademia Bydgoska im. Kazimierza Wielkiego, 2002), 213; Karl A.E. Enenkel, Konrad A. Ottenheym, "The Quest for an Appropriate Past: The Creation of National 
Sometimes he made a conscious decision, but in most cases, it is now difficult to understand why the historian resolved to mention one battle, or peace treaty, or seizure of a throne, or a royal marriage, whilst ignoring others. Only sometimes can we recreate the way of reasoning and comprehend the purpose of using the information. And such is the case of Arild Huitfeldt's work.

The well-known Renaissance tendency to provide the national culture with a new national history ${ }^{6}$, which would be modern and compatible with the demands of the day, was implemented in two ways. One was the attempt to present it in classical Latin, in accordance with the humanist and rhetoric model of history. Such work was supposed to be promoted outside home, as it was addressed mainly to foreigners - they had to be illuminated about the land's glorious past, the noble origins of the nation and its rulers, and its cultural achievements. The national history thus provided arguments in the political discourse and strengthened the nation's honour. In Denmark long-lasting endeavours in that field, unsuccessful in the $16^{\text {th }}$ century, were finally crowned with two Latin works published in the $17^{\text {th }}$ century, written by Johannes Pontanus and Johannes Meursius ${ }^{7}$.

The historian's labour could also have another purpose. Equally political and utilitarian, the picture of the national past could be, written in vernacular, directed at a domestic audience. Its role was to stir up national emotions, strengthen the feelings of loyalty to the ruling dynasty - at the same time offer all necessary evidence to its legitimisation - and support the programme of integrating the country. The educational purpose was also important - by presenting the proper politics, describing errors and

Identities in Early Modern Literature, Scholarship, Architecture and Art", in: The Quest for an Appropriate Past in Literature, Art and Architecture, ed. idem (Leiden, Boston: Brill, 2019), 3; Thomas Haye, "The Construction of National Past in Bella Britannica by Humbert of Montmoret (d. ca. 1525)", in: The Quest, 157-65; Andrzej F. Grabski, "Czy historiografię można uwolnić od mitu?, Przegląd Humanistyczny 40 (1996), 1: 6, 11; Hans-Jürgen Bömelburg, Polska myśl historyczna a humanistyczna historia narodowa (1500-1700), transl. Zbigniew Owczarek (Kraków: Universitas, 2011), 45, 54; Anthony Grafton, What was history? The art of history in early modern Europe (Cambridge University Press, 2007), 31; Daniel R. Woolf, The Idea of History in Early Stuart England, Erudition, Ideology and 'The Light of Truth' from the Accession of James I to the Civil War (University of Toronto Press, 1990), 12; Burke, Renesans, 17, 23; Knud Fabricius, "Cornelius Hamsfort og den danske Bonde", Historisk Tidsskrift, series 10, 26 (1932-1934): 543, accessed 10.06.2021, https://tidsskrift.dk/historisktidsskrift/article/view/49791; Konrad Bielecki, "Etnocentryzm: czy tylko jeden? Krytyczna analiza teorii 'renesansów' Jacka Goody’ego”, Kwartalnik Historyczny, 76 (2019), 3: 443.

6 The idea of Early Modern nationalism is supported by a large number of scholars, like, among recent ones, Caspar Hirschi (The Origins of Nationalism. An alternative History from Ancient Rome to Early Modern Germany, Cambridge University Press, 2012) or Azar Gat (with Alexander Yakobson, Nations. The Long History and Deep Roots of Political Ethnicity and Nationalism, Cambridge University Press 2013).

7 A thorough analysis of both works was presented by Karen Skovgaard Petersen, Historiography at the Court of Christian IV (København: Museum Tusculanum Press, 2002). 
criticising the past wrongdoings, the historian was teaching the king and the readership how to pursue good policy and care for the homeland's wellbeing.

When in the 1530s the major achievement in medieval Danish historiography, the chronicle of Saxo Grammaticus Gesta Danorum ${ }^{8}$, was finally printed, the educated elites in Denmark realised that there is a painful lacuna in the country's history: between the end of the $12^{\text {th }}$ century and the present times there was no equally valuable description of the past. Arild Huitfeldt was one who managed, though for domestic readers only, to fill the gap ${ }^{9}$.

\section{Arild Huitfeldt, his work and his contacts with Poland}

The historian descended both from the distaff and agnate side, from noble families making a rapid career in Dano-Norwegian monarchy. When he was born (1546), the Huitfeldts and Trolle - his mother's kin - belonged to Danish magnates. As other young men of the nobility, Huitfeldt undertook the Grand Tour around Europe, visiting some German and French universities and acquiring perfect knowledge of Latin. Afterwards, in 1571 he entered the royal service, becoming a secretary in the Danish Chancery - at that moment, as historians suspect, he could have started to collect historical documents, of which he made good use later ${ }^{10}$. Soon afterwards he was promoted to the rank of First Secretary - one of the leading figures in Danish administration. After a three-year interruption, when he worked as the headmaster of Herlufsholm School, he was appointed (1586) by King Frederick II Chancellor of the Realm, and thus became a member of the Privy Council, a body which shared the magistrate in Oldenburg monarchy with the king. After the king's death, Huitfeldt was a member of the Regency Council - a close-knit circle of aristocrats ruling the country under minor Christian IV. The new king kept him by his side, entrusting him with diplomatic missions. The historian died in 1609.

8 Danorum regum heroumque historie stilo eleganti a Saxone Grammatico natione Sialandico necnon Roskildensis ecclesie preposito abhinc supra trecentos annos conscripte et nunc primum literaria serie illustrate tersissimeque impresse. ed. Christiern Pedersen ([Paris], 1514).

9 The historian and his work were an object of study of several Danish and Scandinavian sholars like already-mentioned Karen Skovgaard Petersen, Harald Ilsøe (a.o.: En redegørelse for Arild Huitfeldts alment littercere loesning og åndhistorisk baggrund således som det kan loeses ud af hans fortaler til Danmarks Riges krønike og hans kommenterende bemoerkninger i selve dennes tekst (København, 1955); "Arild Huitfeldts Krønike, konfronteret med Anders Sørensen Vedel og eftertiden”, Fund og Forskning, 14, 1967) and representing 19 ${ }^{\text {th }}$ century historiography: Holger F. Rørdam (Historieskriveren Arild Huitfeldt, Danmarks Riges Kansler og Raad, Skoleherre for Herlufsholm, Kjøbenhavn: V. Thaning \& Appel, 1896).

10 Rørdam, Historieskriveren, 48. 
It is astonishing how, being devoted to so many political and administrative duties, Huitfeldt managed to write his immense history of Denmark. Its eight volumes quarto were printed from 1595 to 1603 , covering the period from the legendary beginnings to the death of King Christian III (1559). In the mid-17th century, the second edition was printed, this time in two volumes folio fifteen hundred pages long under the title The Chronicle of the Kingdom of Denmark ${ }^{11}$.

The book enjoyed a widespread popularity. Written in vernacular it soon became a favourite among the reading nobility and almost the official version of Denmark's history at least until the introduction of absolutism (1660), which to some extent annulled its verdict on the previous political system in Denmark. For much longer it was able to influence historical debates and the consciousness of wide circles of the society, whose literacy in the meantime was growing. It was finally replaced by Ludvig Holberg's history of Denmark, published in the $18^{\text {th }}$ century ${ }^{12}$. Up to the $20^{\text {th }}$ century the Danish historians, although many times pointing out the weaknesses of Huitfeldt's book, emphasised how profoundly he influenced them, and their work. However, the historian's opinions were treated as authoritative also by his contemporaries and the next subsequent generations in non-scholarly aspects, mainly in different spheres of politics ${ }^{13}$.

As the chronicler was dealing with the history of his homeland - Denmark, which several times did, or at least tried, to play the role of the hegemon in Northern and Central Europe- he had to include material - names, events - connected with the history of its neighbours: lands located around the Baltic Sea. Doing so, he followed his own hierarchy of importance and interests. The most common and frequent are notes devoted to the Polabian region, the sphere of long-lasting Danish expansion and rivalry with the German states ${ }^{14}$. Then, Huitfeldt was trying to deliver knowledge about the Balticum: Western Pomerania and Gdańsk Pomerania, Livonia and Estonia. Polish history was located only on the third place. These notes on Poland cannot be arranged into a coherent vision: they are fragmented and scattered. To some degree it can be concluded that the native context was one motive for inclusion, a political usefulness another, and sometimes - the exciting character of the "news". Only one exception (in

11 Danmarckis Rigis Krønicke ved Arrild Huitfeld (Kiøbenhaffn: Joachim Moltke, 1652, hereinafter reffered to as DRK/1); Den Anden Tomus eller Part aff Danmarckis Rigis Krønicke (Kiøbenhaffn: Joachim Moltke, 1652, hereinafter reffered to as DRK/2). The digitalised version can be found on: https://archive.org. For more details describing the work see: Krystyna Szelągowska, "Arilda Huitfeldta szlachecka wizja dziejów narodowych Danii”, Roczniki Historyczne 86 (2020): 224-225.

12 Ludvig Holberg, Dannemarks Riges Historie, vol. 1-3 (Kjøbenhavn 1732, 1733, 1735).

13 For more details see: Szelągowska, "Arilda", 223.

14 Recently, Huitfeldt's approach to the Polabian region was described by Paweł Migdalski, Stowiańszczyzna pótnocno-zachodnia w historiografii polskiej, niemieckiej i duńskiej (Wodzisław Śląski: Wydawnictwo Templum, 2019), 95-97. 
fact within the frames of contemporary reality, rather than the past) can be found: the historian has an expert knowledge and clear vision of the political system in the Polish-Lithuanian Commonwealth. Having this narrow scope and visible limits in mind, this study presents this material also because Arild Huitfeldt, the most prominent Danish historian of that period is hardly known in Polish historiography.

The main sources on Polish history for Huitfeldt were the works of Marcin Kromer and Jan Herburt - he mentioned both. He also could find something in Adam of Bremen and more recent works of Albert Krantzius. It is hard to speculate to what degree Polish-Danish relations in Huitfeldt's times had any impact on his interests. It is possible that these made him remember about Poland, but equally important was the contemporary scholarly practice and methods: simply to repeat the sources. Huitfeltd's work has generally an annalistic character, he organises his material along temporal axes, from time to time including separate notes about Poland. Studying Huitfeldt's notes on Polish and Slavonic history (his focus on Pomerania was mentioned above) provides a good opportunity to recognise his scholarly methods. For instance, the historian mentioned the duke Boleslaus Wrymouth several times, and every time he wrote down this name in a different way: Bolslaus, Burislavus and the transcription of the Polish form: Boleslao Crivousto (Bolesław Krzywousty). The same happens with the name of the duke of Posen Przemysł (also king of Poland), who can be called Premislaus or Premislaff. Obviously, it was not easy for a Scandinavian writer to spell the Slavic names correctly, but on the other hand this diversity could be explained also by the simple fact that the historian used varied sources and was writing down the form used. Such a thing is common mainly in the part, which was the paraphrase of Gesta Danorum, which can also be evidence that large parts of this volume, a simple annal, could have been written by the Chancellor's collaborators: secretaries and scribes.

We do not know much about the direct contacts of the Chancellor with Poland. One known interaction occurred when Huitfeldt was in a diplomatic mission in England in 1597. On the way, his ship passed by a Polish vessel on its way back, with Polish ambassador, Paweł Działyński on board ${ }^{15}$. In a diary, written by Huitfeldt's secretary it is noted that the Danish ship saluted the Polish one with gunfire and a trumpet blast ${ }^{16}$. This event was also recorded by a pamphlet, Merkuriusz sarmacki emphasising the elegant and friendly character of the meeting. The text presented the negative outcome of Działyński's mission as a result of Queen Elizabeth's hostility, and not his own doing ${ }^{17}$.

15 Historia dyplomacji polskiej, vol. 2, ed. Zbigniew Wójcik (Warszawa: PWN, 1982), 36-37.

16 [Ludvig Heithman], "Dagbog over de danske Gesandters Rejse til England og Holland in Tillæg til Arild Huitfeldts Levned", ed. Holger Fr. Rørdam, in: H.F. Rørdam, Historieskriveren (in the same volume, but with separate paging), 135 .

17 Merkuriusz sarmacki $z$ Niderlandów i Anglii, czyli zwięzła relacja $z$ dwóch poselstw do Niderlandów i Anglii, które $z$ woli Najjaśniejszego i Najpotężniejszego króla Polski i Szwecji etc., i za zgoda Jego dostojników, senatorów i Sejmu gorliwie i chwalebnie sprawowat i uczynit sławnymi oświecony 
In Huitfeldt's work we come across a small note, showing that, on the margin of great political affairs, the members of a diplomatic mission could make friendly gestures towards each other. When the historian was describing the negotiations concerning Estonia in the $14^{\text {th }}$ century, between the King of Denmark and the Livonian Brothers of the Sword, he mentioned a letter from 1345 where the proposition of selling the country was expressed and informed that the Polish ambassador on the peace congress in Stettin in 1570 donated a copy of this letter to the Danish delegation ${ }^{18}$.

\section{Diverse short notes}

Most of the diverse, scattered and short information, deprived of any comment and usually not connected with the previous or the next one is concerned with alliances, peace treaties, royal marriages or wars and battles, such as Emperor Conrad's victory over the Polish King (sic!) Mieszko and Czechs ${ }^{19}$ or wars between the March of Brandenburg and Poland ${ }^{20}$. One "Polish archbishop" was mentioned as the one who ordained fraudulently the one-eyed bishop Osmund (a story taken from Adam of Brema) to archbishop, allowing him to continue his activity in Sweden ${ }^{21}$. Duke Boleslaus Wrymouth was mentioned as the one whom holy Otto von Bamberg gave support in Christianising the Pomeranian people ${ }^{22}$.

In the $14^{\text {th }}$ and $15^{\text {th }}$ centuries the relations and contacts between Poland and Denmark became more frequent and intense, due to the increasing conflicts in the region between various political forces: the Polish-Lithuanian union, the Brandenburg March, the Teutonic Order, the Holy Roman Empire, not to mention Gdańsk. This is reflected in Huitfeldt's chronicle, when the historian recorded the growing political and diplomatic activity in the region both of Denmark and the Kingdom of Poland.

i wspaniały Paweł Działyński Roku Pańskiego 1597, transl. Irena Horbowy, ed. Ryszard Marciniak (Wrocław: Zakład Narodowy im. Ossolińskich, 1978), 48.

18 Aff dette Breff tilkom os først en Copie, aff det Polske Sendebud til Stettin, paa den Fredsfordrag som giordis imellem Danmarck oc Sverige Aar 1570. DRK/1, 494; One contact described by Huitfeldt's biographer Holger F. Rørdam ([entry: Arild Huitfeldt] in: Dansk biografisk Lexicon, ed. Carl Frederick Bricka, vol. 8 (Kjøbenhavn: Gyldendalske Boghandels Forlag (F. Hegel \& Søn), 1894, 147) about negotiations with the Polish delegation, which came to Denmark in 1604 asking for support is probably based on a mistake.

19 Aar 1027 ofvervant Keyser Conradus de Poler oc deris Konge Mesnigum, med stor ære: hand ofvervant oc de Behmer deris Medhielpere oc tvang de Sclaver under Skat. DRK/1, 69.

20 Aar 1327 giorde de Poler oc Littover stor skade i Lante Marcken. DRK/1, 440.

21 (-) ordinerit i Polen aff en Erckebisp (-). DRK/1, 82.

22 Aar 1118 vaar Bisp Ottho udi stor Flor, som vaar en synderlig hellig Mand, huilcken tilbød oc tilhialp Bolslaum den Polske Hertug at skulle paatage sig Pilgrims gang til det slavoniske Folck, som man kalder Pomerske, oc predike for det groufe Folck Guds Ord; Han omvend dem, ganske aldelis med deris Første Wartislav til Gud. DRK/1, 95. 
Now, the information became more detailed; the author decided also to include documents in extenso, in most cases the treaties signed. This was the alliance signed in 1315 between Eric Menved and Władysław Łokietek, which is explained as being caused by the war with margraves ${ }^{23}$. Two agreements signed by Kings Waldemar Atterdag and Kazimierz Wielki $(1350,1363)$ were also noted and their texts included ${ }^{24}$. However, there is no information about a possible Waldemar's visit in Poland, which confirms a more recent state of knowledge in that matter. There was a long-lasting belief that the Danish king took part in the famous "feast at Wierzynek's" during the international meeting in Cracow in 1364, which is now questioned ${ }^{25}$. A closer cooperation took place in the $15^{\text {th }}$ century, when King Eric of Pomerania signed a peace treaty with Władysław Jagiełło in 1419. Huitfeldt informed the reader about the sole act, the visit of Eric in Poland in 1424 including some details: the occasion was the marriage of the Polish king, the Emperor Sigismund of Luxemburg was present and that negotiations about a marriage of Jagiełło's daughter Hedwig took place with the involvement of the papal delegate. What he did not mention was: the reasons of the treaty, its contexts (the problems with the Teutonic Order) and the fact that the plan of the marriage eventually failed ${ }^{26}$.

Those events were analysed in Polish historiography, thus we know that Huitfeldt committed several minor errors ${ }^{27}$, but more importantly that we are dealing with an annalistic form, so there is no real narrative here - neither interpretations nor reasoning can be found. The notes about diplomatic negotiations on treaties and marriages at the turn of the $15^{\text {th }}$ and $16^{\text {th }}$ centuries have a similar character: in 1507 King Hans was, according to a letter quoted, reconsidering a marriage of his son, Christian, with

$$
\text { In the }
$$
tions in the context of Kazimierz Wielki's foreign policy. However, in his more recent outline (Dzieje
Polski Piastowskiej (VIII wiek - 1370), Wielka Historia Polski, 2, Kraków 1999, 372) this was not re-
peated. Kazimierz Ślaski (Tysiaclecie, 69) mentioned the meeting of both monarchs in 1363, Janusz
Małłek ("Stosunki kulturalne Polski i Litwy z państwami skandynawskimi w późnym średniowieczu
i w czasach nowożytnych (1385/97-1795)", in: Wśród, 67) - specified the years 1350 and 1363 . In theory, there were three possible occasions: Łowicz (1350), Kraków 1363 and therein in 1364, when
the feast took place. The information about Waldemar's presence was announced by Jerzy Wyrozum-
ski (Kazimierz Wielki, Wrocław: Ossolineum, 1982, 138-141), writing about the Polish-Danish relations in the context of Kazimierz Wielki's foreign policy. However, in his more recent outline (Dzieje
Polski Piastowskiej (VIII wiek - 1370), Wielka Historia Polski, 2, Kraków 1999, 372) this was not re-
peated. Kazimierz Ślaski (Tysiaclecie, 69) mentioned the meeting of both monarchs in 1363, Janusz
Małłek ("Stosunki kulturalne Polski i Litwy z państwami skandynawskimi w późnym średniowieczu
i w czasach nowożytnych (1385/97-1795)", in: Wśród, 67) - specified the years 1350 and 1363 . tions in the context of Kazimierz Wielki's foreign policy. However, in his more recent outline (Dzieje
Polski Piastowskiej (VIII wiek - 1370), Wielka Historia Polski, 2, Kraków 1999, 372) this was not re-
peated. Kazimierz Ślaski (Tysiąclecie, 69) mentioned the meeting of both monarchs in 1363, Janusz
Małłek ("Stosunki kulturalne Polski i Litwy z państwami skandynawskimi w późnym średniowieczu
i w czasach nowożytnych (1385/97-1795)", in: Wśród, 67) - specified the years 1350 and 1363 . tions in the context of Kazimierz Wielki's foreign policy. However, in his more recent outline (Dzieje
Polski Piastowskiej (VIII wiek - 1370), Wielka Historia Polski, 2, Kraków 1999, 372) this was not re-
peated. Kazimierz Ślaski (Tysiaclecie, 69) mentioned the meeting of both monarchs in 1363, Janusz
Małłek ("Stosunki kulturalne Polski i Litwy z państwami skandynawskimi w późnym średniowieczu
i w czasach nowożytnych (1385/97-1795)", in: Wśród, 67) - specified the years 1350 and 1363 . tions in the context of Kazimierz Wielki's foreign policy. However, in his more recent outline (Dzieje
Polski Piastowskiej (VIII wiek - 1370), Wielka Historia Polski, 2, Kraków 1999, 372) this was not re-
peated. Kazimierz Ślaski (Tysiaclecie, 69) mentioned the meeting of both monarchs in 1363, Janusz
Małłek ("Stosunki kulturalne Polski i Litwy z państwami skandynawskimi w późnym średniowieczu
i w czasach nowożytnych (1385/97-1795)", in: Wśród, 67) - specified the years 1350 and 1363 .

The festivities in 1424 were on the occasion of the coronation of Sophie, Jagiełł’s wife. See: Zenon Nowak, "Przymierze Polski i Litwy z państwami unii kalmarskiej”, Zapiski Historyczne 34 (1969), 1: 67-78; Idem, “Sprawa przyłączenia Pomorza Słupskiego do Polski w latach 1419-1425”, Zapiski Historyczne 39 (1974), 3: 99-124.

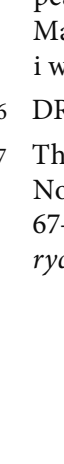

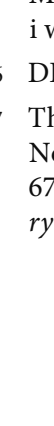


a "Polish maiden"28, an "eternal peace treaty" was mentioned under 1509 - the chronicler noted that this treaty was at the Polish request, and that Denmark was granted "a prime place" - whatever it meant ${ }^{29}$. A few years later, adding no comment at all, the historian mentioned an alliance signed by Hans's successor, King Christian II with Russian Duke Wasilij... against Poland ${ }^{30}$.

Although, as we see, there are no comments from the historian's side, the events in Poland had to be important to some degree, since he decided to mention, under the year 1386 Jagiełło, Duke of Lithuania’s, marriage with Polish King Ludwik Węgierski’s daughter, Jadwiga. It can be explained in two ways: with the fact that the marriage was followed by the duke's Christianisation and adopting the Christian name, which is carefully noted. The other motif could, demonstrating a more modern approach, result from the noting the connection with future events: his son's - Władysław - death in battle (1444) and the marriage of his grand-daughter Anna, who married the duke of Pomerania; here again the importance of Pomeranian history can be seen ${ }^{31}$.

Huitfeldt observed the famous war between Poland and the Teutonic Order from this point of view. When mentioning under the year 1410 the battle at Grunwald (Tannenberg), obviously a sensation in Europe at that time, typically for him, he focused attention on the Pomeranian aspect, describing the actions of the duke of Pomerania and the duke of Szczecin ${ }^{32}$. He also found it worth informing that in the course of the war forty thousand Teutonic Knights died ${ }^{33}$.

Hiutfeldt's interests in Western Pomerania, Dantzig and the politics in the eastern area of the Baltic Sea led to a more detailed account. This is worth a separate study, but in most cases, Poland was not mentioned, since Pomerania had, for a long time, its own independent position and politics. So, only those few notes, when Poland or Polish rulers are directly and clearly named, will be presented. Huitfeldt mentioned the Danish expeditions on Preussen and Sambia and the establishment of Dantzig combined with Christianising the people and the local ruler - Mściwój, who denounced

$$
\text { Po }
$$
Polen, siden hand haffde ladet sig døbe oc bleff hand kaldet udi Daaben Vladislauus. Denne vaar Konning Vladislai Fader i Ungarn, som bleff slagen udi Bugern hos Varnem, Aar 1444. Oc Casimir Kongis tii Polen huis Datter Annam, Hertug Bugislaff aff Pommern den X fick til Ecte., DRK/1, 571.

32 Udi den Marck Tannebierge bleff den Tydske Ordens Mestere slagen aff Jagellone Polono. Hertug Bugislaff i Pommern dragger til Kongen aff Polen i tieniste oc Svantiboer aff Stettin til Ordensfolcket. Hand sender dennem sin Søn Casimir med 600 Heste, huilcken bleff fangen udi Nederlaget oc formedelst Hertug Bugislai Underhandling maatte løse sig for store Penninge. Kongen fordreff Hertug Bugislaff for hans hielp oc Tieniste, nogen Stæder oc Slot. DRK/1, 635. 
his loyalty to the Polish king and made tribute to the Danish Waldemar ${ }^{34}$, The person worth mentioning was the duke Conrad of Mazovia and his alliance with the Poles against Świętopełk ${ }^{35}$. To add drama to his narrative, Huitfeldt recalls the story of the duke Przemysław of Posen, who ordered the strangulation of his wife, Ludgard, with a string ${ }^{36}$.

Huitfeldt did not inform when and how the Teutonic Order settled in Poland, but he did not ignore when it began to affect the political situation in the region. He described the struggle in Hither Pomerania (Vorpommern) over the legacy of local rulers, which engaged all neighbours, including the Order and Poland ${ }^{37}$. He writes how Pommerellen came under Polish rule ${ }^{38}$, about the conflicts between Poland and Pomeranian rulers and their alliance against the March of Brandenburg at the end of the $13^{\text {th }}$ century, summing up that several expeditions by Poles, Brandenburgians and dukes of Western Pomerania tried to win Gdańsk Pomerania ${ }^{39}$.

Although the description of the Pomeranian's fate lacks a coherent form and the threads are not linked, Huitfeldt managed to detect and mention one major turning point - the moment when Dantzig was captured by the Teutonic Order. He described the events in a neutral tone, informing about all issues: the politics of the local voivode, the Brandenburgian's expansion, the Polish king's breach of the agreement with the

34 Aar 1210 skeede it Thog udi Lante Preussen oc Samblant at omvende de Lande til christelige Tro, da blef Mistovi en Polske Første tiltvungen at sverge Konning Woldemar Liudelse. Anno 1164 tilforne haffde hans Herre Fader Konning Woldemar den I. bygt it Slot til Dantzig som Wysselen udløber oc kallet den Haffn Dantzig. Men siden Kong Woldemar vaar bortseyglet tog Sobislaus der Stæd ind igien oc er imellem disse Thog 46 Aar. DRK/1, 178. DRK/1, 203.

36 Samme Aar [1283] lod Premislaus første af Possen hans Hustru Ludgierd quelle med en strick, men de Poler holdt hende for hellig. DRK/1, 287.

37 Ordens Herrerne lade Mestowin quit for hans Faders Gaffue: Mestowin Klaget sig for Paffuen hand sende den Bisp aff Firmian; effter hans Forhandling gaff Mestowin aff sin god Vilie Ordens Herrer det Slot Nowe med 15 Byer der med fick Ordens Folcket først Fod udi Prytzen. Oc effterdi Mestowin saa sig ingen Liffs Arffinge at haffue oc mange effter hands Død skulde ville anmette dennem Rettighed til hans Lande; som var Polen, Pommern, Første aff Ryen oc Greff Adolf aff Holsten. Huilcke begge Herrer haffde hans Døttre oc dernæst ordensherrerne da haffde hand heldst hiulpet hans Frender der til med de Slaver vilde icke der udi bevilge huilcket gaffue tilkiende at deris Forfædre vaare forstøtte aff Forpommern oc derfor hyldiget de Hertug Premislaff der med bleff de rette Arffinge forstøtte, hour offuer stor Blods udgydelse kom offuer Landet. DRK/1, 287-288.

Formedelst Mestowi dødelige Affgang uddøde den hinder Pomerske Linie oc Landene kom under Polen. DRK/I, 308.

39 Effter at Hertug Bugislaus icke vilde affstaa sin arffuelig Rettighed til hinder Pomern drog hand til Belgard oc gandske Landskabet fulde hannem til Ryvolde oc da kom hannem de Poler imod hos den Bukowiske Strand huilcket han nederlagde udi it Slag indtog Ryvolde oc plyndrede det. Paa det sidste forligte sig Wartislaff aff Pommern med Hertug Bugislaff oc effterlod hannem de forøffrede Lande paa det hand skulde bistaa hannem imod Marggreuffen. Der offuer er han med Wladislao dragen udi den Ny Marck oc hafuer Arensvold oc Bergensted forvøstet oc forherget oc skede det Thog om Thog for Pommerens skyld imellem Polen, Marck oc Pommern. DRK/1, 310. 
Knights, and the Order's brutal revenge. He informed (another example of a modern approach to an historical narrative) that the Order possessed the town and the region for one hundred and fifty years ${ }^{40}$.

The complicated problems of Pomerania and its relations with Poland were also present in the $14^{\text {th }}$ century, so again battles, wars and peace treaties were mentioned: so, in the year 1377 Duke Kazimir, in the service of the Polish king, taking part in a siege, was killed by a stone. But the rationale behind this information was sound: the duke's death and the problems with his legacy were important: his duchy was inherited by his brother, who married Marie, who was the daughter of Lady Ingeborg from Mecklenburg, and this couple's son was Duke Eric, who would later become king of Denmark ${ }^{41}$. That is why it was vital to inform the readers about the descent of King Eric of Pomerania: Lady Ingeborg was the daughter of King Waldemar Atterdag and Queen Margaret's sister.

In general, the genealogical connections were always seen as important, and the Early Modern historians usually devoted a lot of space to invoke them and clarify as much as possible. So did Huitfeldt, mentioning some marriages between Slavic, Polish and Pomeranian members of royal families and their Scandinavian, mainly Danish, counterparts. So, the Swedish Prince Magnus married Świętosława, the daughter of Duke Boleslaus Wrymouth ${ }^{42}$; here a mistake was made, since the duke's daughter's name was Ryksa. Another marriage was between the Swedish princess, daughter of King Magnus I Birgersson, called Ladulås and Polish Duke Przemysław ${ }^{43}$.

40 Kongen aff Polen haffde indgiffuet Pomerellen en Weywaade, Peter Swendße Erff kantzler: den same gaff sig under Marggreffuerne med de Slot oc Stræder Stolpe, Schlave, Polno, Karrickel oc Nyenborg: hour ofuer Marggreffueren holt sig gantske Hinderpommeren: huorfore Kongen indtog same Slot, fangede Weywaaden, huilcken dog siden kom løs: Marggrefuerne droge paa Dantzig, erøffrede det, men Slottet beholt en Polisk Høffvitzmand Bogusse, til saa lenge Kong Wladislaff fordret Hoffmesteren aff Prytzen til Hielp oc igien indtog Staden. Nu bleff Hoffmesteren for hans Tieniste oc Krigs omkostning skyld, icke saa snart betalt: der offuer forjagede hand Høffitzmanden Bogusse fra Slottet. Byen kunde hand icke faa, for hand vaar før vel besat. Siden samlede Hoffmesteren meget Krigsfolck aff Ryssland oc giorde Anslag paa Byen oc paa it almindelig Marcket i Dominick neffued, som mange Kremere oc Kiøbmand vaare tilsaammen da haffue hand erøffret Byen eer videre fort dragen, haffuer indtaget Dinhow, Bottno, Lowenborg, Schlato, Canitz, Taathal oc den gandske Land til Stolpen oc haffuer Ordensfolcket same Lande som med Gewalt bleff indtagen, beholt halffandet hundert Aar. Dette er skeed 1302, 12304, 1305 oc nogen Aar effter at dette Larm hafuer været. DRK/1, 323.

41 Aar 1377 bleff Casimir den fierde som udi mange Aar haffde ladet sig bruge udi Kongens aff Polen Tieniste, huorfaare hand oc bleff forlænt med de Lande, Dolbrin oc Braborrig oc haffde der med forøgt sin Titel. Som hand det store Slot Spator i Polen, Kongen til beste haffde belagt, bleff han udi en Storm med en Steen ihjelslagen. Effter hans Død vende de Poler, huis Lande hand haffde fortient, under dem. DRK/1, 564 .

42 Udi dette Aar 1128 tog Hertug Magnus Suenteslavam, Kong Burislavi aff Polen Datter til Hustru, Bryllupet stod i Ribe. DRK/1, 96.

43 Udi dette Aar gifted Kong Magnus i Sverige Rigitz, konning Waldemars datter; hende fick en Polnisk Herre heed Prebislaus: den II hans Broderdatter fik en Herre aff Depholt heed Boloff oc hun Marine. 
In the very detailed account of King Christian III's reign - close to his own experiences and memory, and based on written sources, but also on eyewitnesses' reports, a royal marriage was connected with a diplomatic scandal. This happened in 1555, when the Danish princess Anna, the niece of King Christian, held her marriage in Wismar (1555). Huitfeldt reported that the Danish delegation was offended, because the Polish one was - wrongly, as the Danes claimed - given precedence, i.e. the better position in the hierarchy of guests, so they decided to leave the feast ${ }^{44}$. This story must have been well known in Europe at that time and it was also present in Polish historical books, namely the Chronicle of Poland from 1597, formally by Marcin Bielski, but in the part written by his son, Joachim. In his loose style and with a bit of humour the author describes the event with the final conclusion: the Danes had to "go to the tavern to have supper"45. Also, Holberg wrote about this incident, but his purpose was different: he discovered that Huitfeldt confused the characters of the story (he confused Albrecht of Mecklemburg with Albrecht of Preussen) and did not miss the opportunity to correct the old master ${ }^{46}$.

The last short note concerned with Poland was connected to the Northern Seven Years' War and, as the chronicler admits, it was waged during the reign of the next Danish king, Frederik II. The note describes only the origins of the war - i.e. the comet which in the year 1556 foreshadowed dramatic events to come. In Huitfeldt's eyes the disaster was caused by a conflict in Livonia which was stirred up by the irresponsible and selfish politics of the Polish king, Sigismund Augustus. This was contrary to Christian III, who tried to calm down the tensions and avoid hostilities ${ }^{47}$. The

44 (-) menendis deris Herre at være skeet en Spaat der udi, thi Hans Majest. vaar icke aleeniste Brudens Moderbroder, men ocksaa Danmarckis Rige it ældre Kongerige end Polen, efterdi her udi Danm. Rige udi utænckelige Aar hafuer værit Konger udi den stæd at for stackit Tid Polen haffuer værit en Førstedom. DRK/2, 1548.

45 Kronika Polska, Marcina Bielskiego. Nowo przez Iachima Bielskiego syna iego wydana (Kraków, 1597) (reprint, Warszawa: Graf_ika, 2019).

46 Ludvig Holberg, Dannemarks Riges Historie, vol. 2 (Kjøbenhavn, 1733), 390, accessed on 15.11.2020, http://holbergsskrifter.dk/holberg-public/view?docId=DH\%2FDHTom2.page\&toc.depth=1\&bran$\mathrm{d}=$ \&chunk.id=bd2chap1.

47 Samme aar vaar en stor Comeet paa Himmelen om Vinteren med it forfærdeligt Rijs oc Straaler som udi Tuiffel betyde den store Plage offuer Liffland aff Muscoviteren som er at læse udi den lifflendiske Krønicke. Samme Krig oc Ulycke begyntis først aff indbyrdis Trætte som vaar imellem Hermesteren oc Erckebispen til Riga. Efterdi at Kong Christian som en forstandig Herre saa at det vilde komme paa det sidste Landit til stor Skade oc Affbreck understod hans Majest. sig u daff Fredkierhed at vilde forlige Herremesteren oc Erckebispen huilcken aff Herremesteren vaar fangen oc forsende derfor udi dette Aar sine statlige Sendebud did at forhandle at Bispen icke alleniste maatte komme paa frij Fod igien, men ocksaa den gandske Sag bliffuer forenit før end større Ulycke (som indbyrdis Trette oc Oprør almindelig pleyer effter sig at drage oc nu for de fremmede Giæster skyld huilcke der offuer vaare bleffne indførde i Landit) vaar paa ferde maatte effterfølge. Disse Sendebud handlede saa vit, at altingist vaar saa got som besluttit, at megen Skade haffde kunde bleffuen affveriet, der som de haffde haft sin fremgang. Men effter Kongen aff Polen icke vilde samtycke samme conditions, gick Ilden 
description was a logical conclusion of the official Danish standpoint which accused the Polish expansionist policy in that region of causing the war.

The Renaissance historical books, partly in a medieval manner, were concentrated on politics and its history - the same we see in the case of Hutifeldt's chronicle. In more recent times, however, the confessional problems became vital as well. So also in this aspect a piece of information with a Polish thread can be found. During the reign of Christian III the relations between various protestant creeds became hostile and for the Danish Church and the king himself the defence of pure Lutheran doctrine was seen as raison d'état. This is probably why Huitfeldt decided to include the information about a short visit in Denmark of Jan Łaski, also because in this way he managed to explain the origins of one decree, issued (1559) by Christian III - a decree forbidding the supporters of the anabaptist movement to enter the monarchy. Around two hundred refugees from England, whose escape was caused by the persecution of the catholic Queen Mary Tudor, came to Denmark. Huitfeldt does not specify the moment of their arrival, connecting it directly with the above-mentioned decree, but in fact they came six years earlier, in 1553. Among them, one "Johannes aff Lask", a Polish nobleman. The king organised a theological debate between newcomers and the leaders of the Danish Church but he did not accept the point of view of the former and ordered them to leave the country immediately. Huitfeldt, using an account of one of the refugees, whom he called "Carolus Utenhoff" (in fact it was Johannes van Utenhove, 1516-1566, a Flemish humanist and religious reformer), reports that all this happened during a severe winter ${ }^{48}$. Contrary to the historian's description, which is not exact, the debate was waged not in person, but only in the form of exchange of letters between the Danish bishop Peder Palladius ${ }^{49}$ and other members of the group, and Łaski did not participate in $i^{50}$.

\section{The story about Petrus Duvinus}

In most cases, the notes and information about Poland had limited character, although coming closer to his contemporary time, the chronicler made them more extensive.

i brand, oc ødelagde paa se sidste icke alleniste den Ganske Orden oc Landit men strackte sig ocksaa til andre Naboer. DRK/2, 1552.

Ibidem, 1548-1549.

49 Peder Palladius, 1503-1560, lutheran cleric, bishop (superintendent) of Zealand from 1537; a prominent promoter of the Lutheran church in Denmark.

50 Kai E. Jordt Jørgensen, "Jan Laskis Besøg i Danmark, Vinteren 1553". Teologisk Tidsskrift for den danske Folkekirke, series 5, 6 (1935), 92, 94. 
Nevertheless, in some circumstances, the stories are slightly longer. There are three such examples, all strictly connected with Danish history.

The first deals with the well-known story about Piotr Włostowic, a Silesian magnate in the $12^{\text {th }}$ century, an important figure in Polish politics of that day.

Under the year 1149 Huitfeldt noted the death of "Petrus Duvinus", a Dane, who, despite his good position in his homeland, came with his father, a wealthy man, to Poland and joined the service of King (sic!) Bolesław III (the Wrymouth). He won respect and sympathy of the king, but (after his death) lost the favours of his son, duke Władysław, because he dared to mock his wife. The duchess accused him of treason, and he was blinded and muted in 1144 and finally died in 1149. Huitfeldt mentioned that he founded a monastery in Breslau where he was buried and quoted the epitaph on his tomb ${ }^{51}$. Huitfeldt described the whole story, following the book of the Silesian chronicler Joachim Curäus (1532-1573): Gentis Silesiae annales complectente... (Wittenberg 1571).

Another moment when the historian came across the same, or a similar, story happened when he was describing the tragical reign of the Danish King Eric Plovpenning (1216-1250). He referenced “Polish chronicklers” („Polniske Krønickeskriffuer”), i.e. Marcin Kromer ${ }^{52}$ and Jan Herburt - both copied the story from a medieval, $13^{\text {th }}$ century text, Wielkopolska Chronickle. In this version, Peter ("Petrus Avinus til Breslow"), the son of a certain William, the knight of King Eric, made a career in the court of the Polish King Bolesław. When the Danish king was killed (1250) William asked his son to convince Bolesław to organise an expedition to Denmark to avenge the murder of King Eric and punish his killers, mainly his brother Abel. At the same time another motive was to rescue and take away the Danish treasure, in order not to let them fall into the assassin's hands. Following Kromer and Herburt, Huitfeldt gave an account of the expedition and its consequences: the Danish Royal Council offered Bolesław the Danish crown, which he refused to take ${ }^{53}$.

51 Aaret derefter [1149] døde udi Slesien Petrus Duvinus, en Dansk, som hafuer bygt oc funderit S. Vincentij closter til Breslaw, som er aff Præmonstratenser orden: Hans Epithaphium eller Graffskrifft liuder saaledis: Hic situs est Petrus, Maria conjuge fretus / Marmore spledente, patre Vilhelmo peragente / Han vaar høyt anseet udi hans Fæderne Land dog drog hand derudi uvist aff hvad Aarsage til Kong Boleslaum den 3. udi Polen, som da oc haffde Slesien, med sin Fader som vaar en rig Mand. Hos hannem bleff han æret oc anseet: Han fick en begrædelig Affgang, for hand skiemtet noget for rundeligen med Christina Wladislai Hustru, Keyser Henrich den 5. Datter thi begge Øyene bleff hanem udstunge oc hans Tunge affskaaren, huilcket skeed Aar 1144. Hand Leffde endda 5 Aar efter, døde Aar 1149. DRK/1, 103.

52 The story was described by Marcin Kromer twice: Kronika Polska Marcina Kromera biskupa warmińskiego (Sanok, 1857), 258-259, 285-288.

53 Men effterdi disse Sager som nu ere repeterit, blifue tillagt Boleslao Crivousto, huilcken Aar 1139 er Død, oc derfor mange Aar for denne tid, nemlig 1250 Aar, saa lader jeg saadant hafue sin Besked oc Maade. De Danske Annaler melde intet der om, at saadant paa denne eller nogen tid tilforne skulle haffue været skeed. men udi den Slesiske Historie finder jeg, at Aar 1149, skal en Dansk været Død, 
Huitfeldt immediately realised the weaknesses of this story and critically commented that Peter had lived in the previous century, as it was described under the year 1149 (once again he told the whole story). He also pointed out that the Danish annals do not mention such events and concludes - which shows his modern abilities as an historian - that the story was much better adjusted to the historical realities of the $12^{\text {th }}$ century, not the $13^{\text {th }} 54$.

The story of the Polish conquest of Denmark was also repeated by a Danish $17^{\text {th }}$ century historian Claus C. Lyschander in his work Danske kongers slectebog. Here the author made a reference to Polish historians $s^{55}$, but certainly he also knew that it was present in Huitfeldt's authoritative book. Lyschander did not critically comment on the story, just repeated it, but, being an expert in chronology and following Huitfeldt's remark, he associated it with the assassination of the Danish King Eric Emune in $1137^{56}$.

Also, Holberg decided to accept the story in part; this time in the context of the dramatic murder of Duke Kanut Lavard (1131). Referencing Kromer, he only mentioned that this event initiated the period of civil wars in Denmark and because of that, many magnates left the country, among them "Lord William, father of Peder Dumes [sic], who went to Poland (-)"s7. Certainly, Holberg did not write anything about the Polish conquest of Denmark. In this way, the Polish legend was absorbed, for a while, into Danish historiography, although purified of most uncredible elements.

\section{Thirteen Years' War}

The second larger story related to the Thirteen Years' War (1454-1466) and Huitfeldt's description is focused only on Danish and Swedish participation. Danish engagement was a direct consequence of the Swedish one, since at that time the primary object of Danish politics was to preserve the Kalmar union, and counter back all Swedish

hed Petrus Duvinus udi S. Vincentij Kloster som vaar af Praemonstratensis Orden, hos Breslow, som hand før haffde stifftit, huilcken haffuer en saadan Graffskift (-). DRK/1, 228.

54 Den Historie som Curäus reciter, kommer bedre ofuer ens for Tidens, Naffnens oc Omstendens Skyld til forrige Tide end her. DRK/1, 228.

55 The author informed that he used the collection Polonicarum rerum latini veteres et recentiores scriptores quotquot exstant, Basel 1582 by Johannes Pistorius.

56 Claus Christopher Lyschander, Synopsis historiarum Danicarum ... den Danske historia ... forfatted vdi de Danske kongers slectebog (Kiøbenhaffn, 1622), 428-429, accessed on 18.09.2020, https:// books.google.pl/books?id=NLtBAAAAcAAJ\&printsec $=$ frontcover\&hl=pl\&source=gbs_ge_summary_r\&cad $=0 \# \mathrm{v}=$ onepage\& $\mathrm{q} \& \mathrm{f}=$ false.

57 (-) Herr Wilhelm Peder Dumes Fader, hvilken gick til Polen (-), Ludvig Holberg, Dannemarks Riges Historie, vol.1 (Kjøbenhavn, 1732), 210, accessed on 15.10.2020, http://holbergsskrifter.dk/holberg-public/view?docId=DH\%2FDHTom2.page\&toc.depth=1\&brand=\&chunk.id=bd2chap1. 
attempts to win independence. The major actors were, thus, King Christian I and the Swede Karl Knutsson Bonde (Charles VIII).

Being aware of the real character of Danish politics during the war - Huitfeldt understood without any doubts that the most important part was the Swedish issue - the historian, though not always coherently, describes other aspects as well. He correctly associates the war with the rebellion of the Prussian towns against the Teutonic Order, placing its start in 1457. Danish engagement is presented as a result of pleas from the Orders side - the Knights asked the western rulers (including the Emperor) to put sanctions (i.e. to forbid the trade) on the Prussian towns ${ }^{58}$.

So, the history goes on: King Christian sent a letter to Kazimierz Jagiellończyk, pointing out with deep sorrow, how the Order made a name for itself in defending Christianity not only in Syria, but also in Eastern Europe, how dangerous the Polish king's action could be, encouraging other pagan nations in the region to fight against it. He reminded Kazimierz that he pledged to protect the Christian religion and preserve good relations with the Order. Finally, he included a threat: if Kazimierz does not abandon the politics of supporting the rebellious towns, he, Christian, would have to act against him, and also against those towns, especially Gdańsk, Elbląg and Toruń. Incidentally, this letter revealed how much the Danish king was influenced by the Teutonic Order's narrative about its activity in the Middle East and Eastern Europe - repeating the phrases about "pagan people" who were supposed to still live in the region.

But soon, other information, in fact, presented a much more realistic picture of the motives of his engagement. When Christian issued the orders forbidding any trade with Gdańsk, he explained that the major reason related to the fact that the city's ships violated the law, since they were sailing from the Baltic Sea to the Northern Sea, not through the Sund, where they would have to pay the customs, but took another route the Danish straits. Another reason was the fact that Gdańsk supported the enemy of Denmark, Karl Knutsson. And finally, the third reason was described. This was connected with an incident which happened a few years before - Huitfeldt (twice) pictures a humiliating situation for the Danish king, when he, sailing along Norwegian shores during the storm, wanted to seek shelter in one port, and this was prevented by some Gdańsk vessels, which began to shoot cannons against the Danish ships, so the king had to stay at sea the whole night. The Gdańsk merchants are also portrayed as real pirates, who attack Danish ships, capturing the crews and the goods $s^{59}$.

58 Aar 1457 begyntis en stor Krig oc Oprør udi Lante Prytzen, imellem Undersaatterne oc Ordens Herrer, en Part de Prydske Stæder gaffue sig under Kong Casimiro aff Polen, en Part tog hand med Krigsmact ind, huilcket fortrød Keyseren, Churførster oc andre Herrer, saa at de saa vel i Ordens Herrer besøgte Kong Christiern, at forbiude all Tilføring paa same frafaldne Prydske Stæder, oc ellers Handel oc Vandel udi hans Riger at bruge. DRK/2, 869.

59 Vaar Kongen for nogle Aar siden i Norge oc for Storm skyld vilde været ud I en Haffn, da skiød de imod hannem, saa hand ikcke maatte komme udi sin egen Haffn dog der vaar Platz til flere Skibe, saa 
The incident in the first description was commented on as a "joke", for which "they soon would pay dearly" (...en Spaat ...huilcket hand dennem siden dyrt nock betalde) ${ }^{60}$.

The description of the war is focused on the activity of the Swedish part, particularly Karl Knutsson, combined with the politics of Gdańsk. The negative attitude towards this city did not prevent Huitfeldt to portray its mayor, Reinhold Niderhof, as brave and determined in fighting against the Order for freedom - this was during the armistice negotiations in Stockholm, when he dared to oppose the Danish king, presenting the Teutonic Order as a traitorous, aggressive and tyrannic organisation which would never be accepted by the people of Gdańsk, loyal to the Polish king ${ }^{61}$.

Typical for the period lack of coherence, the historian does not inform how the war ended (losing his interest at the moment when Denmark abandoned the case) - in the year 1466 (when the peace treaty in Torun was signed) he mentioned only the plans of a royal marriage between the Danish Crown Prince Hans and Sophie, the 2-year-old daughter of Kazimierz Jagiellończyk, which did not come to fruition ${ }^{62}$.

\section{King Christian II and Melchior}

Finally, the third story in which Poland played some role, though rather passive, was connected with the whole narrative about King Christian II's reign, and specifically the judgement of the king, in which Huitfeldt in fact presented the official position of the contemporaneous Danish government.

Under the year 1520, noting (slightly incorrectly) the beginning of the war between Poland and Ducal Prussia (the secularized Teutonic Order state), he precisely informed that the war was caused by the fact that Prince Albrecht Hohenzollern did not want to

hand den hele Nat hafuer maat holdet Søen til med, da falder de undertiden udi Land oc bortfører hand Undersaatter oc deris Gods. DRK/2, 869-870.

60 Ibidem, 860.

61 Omsier bleff en Dag Anstillet til Stockholm om en anstand. Did bleff paa Kongen aff Polens oc de Dantzigers vegne forsendt Her Reinhold Niderhof Borgemester oc Her Bernt Bapst Raadmand huilcke bleffue afferdiget med Siu Skibe til Stockholm under Kong Christierns Leyde der vaar oc Hertugens aff Slesvig oc de Lybske Sendebud hos oc første gang bleff intet skaffet thi Kongen vilde at Ordens Herren med skulde indragis i Handelen oc da Niderhof haffde sagt at Kongen aff Polen oc hans Undersaaatter at vaaret vaare anfalden oc fiendligen antastet huilcker saadan en Potentat icke burde, da kom det til saadan en Forbittring, at Kongen foer ud oc sagde ere i icke tilforn undsagde nock [wyzwani "na pojedynek] saa undsiger jeg eder endnu paa mine Tre Rigers vegne, Kongen aff Polen oc alle hand Lande, Særdelis Prytzen oc Dantzig. Herr Niderhoff undsagde hannem igien paa Kongen aff Polens oc Dantzigers Byes vegne, sigendis der hos Kongen skulde aldrig leffue den Dag at de igien skulde tage de Tyrraner de Krytze Herrer. Der bleff samme Møde split at oc de Dantziger seylet igien hiem oc komme til Dantzig S. Hans Afften. DRK/2, 873.

62 Ibidem, 909 
pay homage to the Polish king, Sigismund [I the Old] ${ }^{63}$. Again, Denmark was involved in the events, because, as Huitfeldt informed, Christian sent a military unit to support Prussia. According to Huitfeldt, it was the same unit which was previously sent from Poland to Denmark to help in the war with Sweden. The Polish king then sent an envoy, named Melchior, with a letter in which he asked the Danish king about his plan and reasons and criticised the Danish decision. Huitfeldt reported that, at the first moment, the king of Denmark, in an apology, explained he knew nothing about sending the unit to Prussia, and such a response was taken by the ambassador back home. But soon Christian changed his mind and ordered some vessels to chase the Polish ship and murder Melchior under a disguise of a pirate attack $^{64}$.

Several times in his book, when expressing the opinion about King Christian II and his rule, Huitfeldt mentioned that incident, stressing that this was an extremely barbaric act: "Even the Turks do not kill any envoy sent to them [in a diplomatic mission]!" ${ }^{65}$. Some evidence is also provided: the next Danish king, Frederick I, writing in his letter - an accusation of Christian to legitimise his dethroning, mentioned three golden rings he saw in Christian's hands, recognising them as being the ambassador's possessions.

This story was well known in Denmark then, and was also included into the s.c. Skibby Chronicle (Skibbykrønike) of Poul Helgesen. This book was unknown until the $17^{\text {th }}$ century, so Huitfeldt must have used another source ${ }^{66}$. Nevertheless, the story is mysterious, since it cannot be confirmed by another source. Even Marcin Kromer in his book about the fate of Katharina Jagiellonka did not mention it, though he included a description of Christian II as godless, malicious and cruel ${ }^{67}$. It is impossible to assume that if he had known anything about the murder of the Polish ambassador, he would have omitted it. Holberg in his Danish history quoted two official documents: the letter-statement of Frederick I and the official announcement of the Royal Coun-

63 Samme tid [1520] vaar der en Krig begynt imellem Kong Sigismundum aff Polen oc Hertug Albrit aff Pryssen, aff den Aarsage, Hertugen aff Pryssen icke vilde giøre de Poler nogen Læns Eed oc Forplict, men holt sig aldelis saa vel for den Tydske Aardenn Skyld, som ellers i andre maade at ligge under den Romerske Rige aff saadan Tvist giorde de Poler stor skade udi pryssen, de andre igien paa de Polske Undersaatter. DRK/2, 1152. Ibidem, 1161-1162.

65 Kongens Sendedbud aff Polen lod hand omkomme udi den Østre Strand, som er uhørlig iblant Christen Folck. Ja end ey iblant Tyrcker et Sendebud som til hannem selff sendis skulde belegedis oc skadis., DRK/2, unnumbered dedication to Christian IV, also 1162.

66 Ślaski, Tysiąclecie, 141 [Poul Helgesen], "Den skibyske Krønike”, in: Monumenta Historiae Danicae, ed. H. F. Rørdam, vol. 1 (Kiøbenhavn: G.E.C. GAD, 1873), 52; Poul Helgesen (ca.1485-after 1534) was a Catholic, his latin chronickle mainly focus on the reformation in Denmark, of which he was a fierce enemy; the manuscript of his work, ending in 1534, was hidden in a wall of the church in Skibby and was discovered in 1650 .

67 Marcin Kromer, Historyja prawdziwa o przygodzie żałosnej książęcia finlandzkiego Jana i królewny polskiej Katarzyny, ed. Janusz Małłek (Olsztyn: Pojezierze, 1983), 14-15. 
cil. Both explain the reason why the Danish people and the Royal Council decided to perform such an extreme action as overthrowing their own king. The assassination of Melchior was not mentioned in either of them ${ }^{68}$.

So, most probably this history is false, being a part of the black legend of Christian II, being carefully constructed over a long time, and gradually enriched by most extreme details, showing the king as a felon and a man willing to violate any law. Huitfeldt probably used one of many pamphlets, written and published during the internal struggle in Denmark.

\section{Huitfeldt's opinion about the Commonwealth's political system}

Finally, one more aspect of Huitfeldt's interests in Poland should be analysed.

As a statesman and politician, Huitfeldt had good knowledge about the political system in the Polish-Lithuanian Commonwealth, the democracy based on the nobility's predominance and its government. Such references were often put mainly in the author's prefaces, by which he provided the young king (Christian IV) with political expertise. The teaching was partly of a moral character - the historian wanted to show the king examples of a proper ruler, his policy and behaviour. He also wanted to present the Danish political system as not only the best one, but also as something more natural, being a product of historical evolution and strongly connected with tradition. The basic elements of the system were the election of the king, and the leading position of the Privy Council in the government. He saw the political system in the Commonwealth as good evidence confirming that diagnosis. Several times he emphasised that Denmark is a "free elective monarchy", and the Polish example was proof that it could not be seen as an aberrancy. It was vital to point to the elective character of the monarchy in the context of the changes in the early $16^{\text {th }}$ century and the dethronement of Christian II.

So, the old chancellor admonished the king:

$(-)$ at the beginning the Estates of this kingdom simultaneously made an oath and elected Your Majesty, to lay the legal government [in your hands], just as Your ancestors had [been given]. It was because this kingdom is not a hereditary monarchy, but a free elective one. At the beginnings there were no hereditary kingdoms or other magistrates, such as we see today, but the people were choosing the one who was most clever, diligent

68 Ludvig Holberg, Dannemarks Riges Historie, vol. 2, 141-158. Similarily, Polish historiography does not menion it at all, see: Andrzej Wyczański, "Polska służba dyplomatyczna 1506-1530", in: Polska stużba dyplomatyczna XVI-XVIII wieku, ed. Zbigniew Wójcik (Warszawa: PWN, 1966), 11-79 (and a list of individuals active in the Polish contemporaneous diplomacy included, 69-70). 
and fit. And some states, i.e. this kingdom [Denmark] and Poland still preserve the ancient habit ${ }^{69}$.

The elective monarch was, thus, according to Huitfeldt, the most natural and traditional form of government, which has been created for the common good, and its structures, i.e. offices - including the royal one - have to serve the people.

In particular he provided information about Henry de Valois, who, as he wrote, did not want to live in Poland, but in France, so the Poles decided to choose another ruler ${ }^{70}$.

The historian notes the similarity of governing principles: the democratic idea that the state does not belong to the king, or dynasty, but the people. He remarked that supreme officials make an oath of allegiance not only to the ruling king, but they swear to take care of the whole country (men oc Riget at skulde vide diss Beste). In Denmark, he continued, we have a chancellor, a hofmeister, a marshal and other members of the Privy Council. In Poland: a voivode and a castellan ${ }^{71}$. Poland is also listed as a country which adopted (together with England, Scotland, the Italians and the French) a good military system. It rejected the mercenary army, replacing it with “one's own one", an army consisting of conscripted locals. Huitfeldt presented this idea as a piece of advice to the king, convincing that - as history shows - the mercenaries are always troublesome $^{72}$.

The information about the Polish system provided by Huitfeldt belong to those, which in the book have a consistent and coherent character: they were repeated in the same form several times, so it is clear that the historian had analysed the topic and came to the conclusion. Probably this relates to the utilitarian character of Huitfeldt's book: he wanted to air the conviction that the Danish system: the elective monarchy with a strong position of the Privy Council, representing the people, is a natural product of historical development and certainly can be placed within the European tradition. This was confirmed by the Polish example: as the political system did not hinder making it a strong state, so similarly Denmark with its form of government can preserve its role as the hegemon in Northern Europe.

69 (-) haffuer disse Rigers Stender samptlig hyldit, sorit oc udvald Eders Maj. oc derhen seet, oc til det lofflige Regiment, som Eders fremfarne Forældre haffue ført, huilcke Kongedomme icke er nogle Arfferige men fri Valriger. Aff første da vaare ingen Kongeriger eller Herschaff Arfflige, som nu en Part ere, men da tilstickede oc udvalde Folckit den, som dydeligste, Forstandigst oc Beqvemmeligst vaar. Ved same Skick er dette Rige, Polen oc nogle fleere udi Christendommen aff langsommelig Brug oc Indskickelse bleffne., DRK/2, in unnumbered dedication to Christian IV. de Poler at være træd til it ny Vall, der Kong Henrich den anden icke vilde bo hos dennem udi Polen, men udi Franckrige. DRK/2, 1210.

$\mathrm{DRK} / 2,1211$. 


\section{Conclusion}

All the notes and information about Poland included in Arild Huitfeldt's chronicle do not compose a full and coherent picture. The historian focused his attention of his own national history and usually referenced Poland, when some connections were visible: the royal marriages, treaties or alliances: those had to be scrupulously, in an annalistic manner, registered. He also presented information which involved Denmark directly like the story about Peter the Dane. Some events, though, were so well known, like the battle at Grunwald, that even though they had nothing to do with the history of Denmark, they could not be omitted.

When delivering the political and ideological lessons Huitfeldt used the Polish example in a consistent way - here it was logical to mention the political system of the Commonwealth as similar to the Danish one, as proof that the Danish elective monarchy was not an anomaly, but proper and stable and other European countries had the same kind of monarchy. He stressed that everywhere it was a product of historical development and a system growing out of the tradition. The story about Melchior became also useful to accuse King Christian II, presented here as a brutal, cruel tyrant, violating the law.

Still, this analysis does not clearly show, whether there is much or little information about Poland. This question can be answered by some comparisons with notes concerning other Eastern or Central European countries, such as, for instance, the Czech Republic (Bohemia in contemporaneous practice) or Hungary, incidentally being a country with, to some degree, a similar social and political system to the Polish one. This question probably could be an object of scrupulous analysis, but for the purpose of this paper, only a quick glance would suffice.

In the huge, more than three hundred folio pages (not paginated) large register of names and terms, at the end of the second volume of Huitfeldt's work, the term "Poland" is included in five entries (certainly, other notes are listed in other contexts, like ruler's names). In the case of both the Czech Republic and Hungary, there is none. Some notes, however, can be found. Both countries' names are usually evoked in connection with the information about the Holy Emperor's activities, since, for some time, they possessed the Crowns of those. Separately, Hungary is mentioned in the history of Eric of Pomeranian's journey south to meet the emperor (1424), when the Danish king was travelling across this country ${ }^{73}$. Some other annalistic remarks inform that Bohemians became Christians in 893, about the Hungarian King Bela's marriage, that Hungarians were defeated by the Turks (1304) or that the Bohemian King Wenceslaus was killed by his brother Boleslaus (974). There are also a few sentences - long note 
about the burning at the stake of Jan Hus from Prague ("Johannes Huss, Pragensis"). The short note is concluded with a moral sentence: that is how heretics end ${ }^{74}$. Obviously Huitfeldt did not realise, that Hus was in fact a predecessor of Protestantism, and repeated conclusions from his source, which was the common opinion of Europeans at that time. This could also result from his Lutheran standpoint, which at the end of the $16^{\text {th }}$ century excluded any variation of the non-Catholic creeds, except the strict Lutheran one.

It seems that Huitfeldt had a much better awareness and interest in Poland and her history than other Eastern and Central European countries. First and foremost, because of the real connections between the two countries and geographical location - in his eyes, Poland was probably a part of Northern Europe, involved in affairs and politics of the Baltic region.

\section{Bibliography}

Bielecki, Konrad. "Etnocentryzm: czy tylko jeden? Krytyczna analiza teorii 'renesansów' Jacka Goody'ego”. Kwartalnik Historyczny 76 (2019), 3: 425-452.

Bielski, Marcin. Kronika Polska, Marcina Bielskiego. Nowo przez Ioachima Bielskiego syna iego wydana (-). Kraków 1597 (reprint), Warszawa: Wydawnictwo Graf_ika, 2019.

Biskup, Marian. Trzynastoletnia wojna z Zakonem Krzyżackim 1454-1466. Warszawa: Wydawnictwo MON, 1967.

Bömelburg Hans-Jürgen. Polska myśl historyczna a humanistyczna historia narodowa (1500-1700). Transl. Zbigniew Owczarek, Kraków: Universitas, 2011.

Burke, Peter. Renesans. Transl. Ewa Elżbieta Nowakowska, Kraków: Wydawnictwa UJ, 2009.

Czapliński, Władysław. Polska a Dania XVI-XX w. Warszawa: PWN, 1976.

Długopolski, Edmund. Władysław Łokietek na tle swoich czasów. Kraków: Universitas, 2009.

Enenkel, Karl A.E., Ottenheym, Konrad A. "The Quest for an Appropriate Past: The Creation of National Identities in Early Modern Literature, Scholarship, Architecture and Art". In: The Quest for an Appropriate Past in Literature, Art and Architecture ed. Idem, 1-12. Leiden, Boston: Brill, 2019.

Fabricius, Knud. "Cornelius Hamsfort og den danske Bonde", Historisk Tidsskrift, series 10, 26 (1932-1934), 543. Accessed 10.06.2021. https://tidsskrift.dk/historisktidsskrift/ article/view/49791. 
Garlicki, Andrzej. “Przedmowa”. In: Sąsiedzi i inni, ed. Andrzej Garlicki, 5-6. Warszawa: Czytelnik, 1978.

Gat, Azar. (With Alexander Yakobson). Nations. The Long History and Deep Roots of Political Ethnicity and Nationalism. Cambridge: Cambridge University Press 2013.

Grabski, Andrzej Feliks. “Czy historiografię można uwolnić od mitu?”. Przegląd Humanistyczny 40 (1996), 1: 1-17.

Grabski, Andrzej F. Polska w opiniach Europy Zachodniej XIV-XV wiek. Warszawa: PWN, 1968.

Grabski, Andrzej F. Polska w opiniach obcych X-XII wiek. Warszawa: PWN, 1964.

Grafton, Anthony. What was history? The art of history in early modern Europe. Cambridge: Cambridge University Press, 2007.

Hanusiewicz-Lavallee, Mirosława, ed. Wśród krajów Północy. Kultura Pierwszej Rzeczypospolitej wobec narodów germańskich, słowiańskich i naddunajskich: mapa spotkań, przestrzenie dialogu. Warszawa: Wydawnictwo Uniwersytetu Warszawskiego, 2015.

Haye, Thomas. "The Construction of National Past in Bella Britannica by Humbert of Montmoret (d. ca. 1525)". In: The Quest for an Appropriate Past in Literature, Art and Architecture, ed. Karl A.E. Enenkel, Konrad A. Ottenheym, 153-166. Leiden, Boston: Brill, 2019. DOI: https://doi.org/10.1163/9789004378216_008.

[Heithman, Ludvig]. “Dagbog over de danske Gesandters Rejse til England og Holland in Tillæg til Arild Huitfeldts Levned”, ed. Holger Fr. Rørdam. In: H.F. Rørdam, Historieskriveren Arild Huitfeldt, Danmarks Riges Kansler og Raad, Skoleherre for Herlufsholm. Kjøbenhavn: V. Thaning \& Appel, 1896.

[Helgesen, Poul]. “Den skibyske Krønike”. In: Monumenta Historiae Danicae, ed. H.F. Rørdam, vol.1, Kiøbenhavn: G.E.C. GAD, 1873.

Hirschi, Caspar. The Origins of Nationalism. An alternative History from Ancient Rome to Early Modern Germany. Cambridge: Cambridge University Press, 2012.

Holberg, Ludvig. Dannemarks Riges Historie. Vol. 1, Kjøbenhavn, 1732. Accessed on 15.10.2020. http://holbergsskrifter.dk/holberg-public/view?docId=DH\%2FDHTom2. page\&toc.depth=1\&brand=\&chunk.id=bd2chap1; Vol. 2, Kjøbenhavn, 1733. Accessed on 06.10.2019.http://holbergsskrifter.dk/holberg-public/view?docId=DH\%2FDHTom2. page\&toc.depth=1\&brand=\&chunk.id=bd2chap1.

[Huitfeldt, Arild]. Danmarckis Rigis Krønicke... (-). vol. 1-2, Kiøbenhaffn: Joachim Moltke, 1652.

Ilsøe, Harald. “Arild Huitfeldts Krønike konfronteret med Anders Sørensen Vedel og eftertiden”. Fund og Forskning 14 (1967): 23-58.

Jørgensen, Kai E. Jordt. “Jan Laskis Besøg i Danmark, Vinteren 1553”. Teologisk Tidsskrift for den danske Folkekirke, series 5 (1935), 6: 81-116.

Kot, Stanisław. Rzeczpospolita Polska w literaturze politycznej Zachodu. Kraków 1919. 
Kromer, Marcin. Historyja prawdziwa o przygodzie żałosnej książęcia finlandzkiego Jana i królewny polskiej Katarzyny, ed. Janusz Małłek, Olsztyn: Pojezierze, 1983.

Kromer, Marcin. Kronika Polska Marcina Kromera biskupa warmińskiego ksiag XXX (-). Sanok 1857.

Libiszowska, Zofia. “Zainteresowanie Polską w historiografii francuskiej XVI i XVII wieku”. Zeszyty Naukowe Uniwersytetu Łódzkiego, Nauki Humanistyczno-Społeczne, series 1, 12 (1959): 63-82.

Lyschander, Claus Christoffer. Synopsis historiarum Danicarum ... den Danske historia... forfatted vdi de Danske kongers slectebog. Kiøbenhaffn: Henrich Waldkirch, 1622. Accessed on 18.09.2020. https://books.google.pl/ books?id=NLtBAAAAcAAJ\&printsec=frontcover\&hl=pl\&source=gbs_ge_ summary_r\&cad $=0 \# \mathrm{v}=$ onepage $\& \mathrm{q} \& \mathrm{f}=$ false.

Małłek, Janusz. “Stosunki kulturalne Polski i Litwy z państwami skandynawskimi w późnym średniowieczu i w czasach nowożytnych (1385/97-1795)”. In: Wśród krajów Północy. Kultura Pierwszej Rzeczypospolitej wobec narodów germańskich, słowiańskich i naddunajskich: mapa spotkań, przestrzenie dialogu, ed. Mirosława HanusiewiczLavallee, 58-102. Warszawa: Wydawnictwo Uniwersytetu Warszawskiego, 2015.

Merkuriusz sarmacki $z$ Niderlandów i Anglii, czyli zwięzła relacja $z$ dwóch poselstw do Niderlandów i Anglii, które z woli Najjaśniejszego i Najpotężniejszego króla Polski i Szwecji etc., i za zgoda Jego dostojników, senatorów i Sejmu gorliwie i chwalebnie sprawował i uczynił sławnymi oświecony i wspaniały Paweł Działyński Roku Pańskiego 1597. Transl. Irena Horbowy, ed. Ryszard Marciniak, Wrocław: Zakład Narodowy im. Ossolińskich 1978.

Migdalski, Paweł. Słowiańszczyzna północno-zachodnia w historiografii polskiej, niemieckiej i duńskiej. Wodzisław Śląski: Wydawnictwo Templum, 2019.

Nowak, Zenon. "Przymierze Polski i Litwy z państwami unii kalmarskiej”. Zapiski Historyczne, 34 (1969), 3: 45-78.

Nowak, Zenon. “Sprawa przyłączenia Pomorza Słupskiego do Polski w latach 1419-1425”. Zapiski Historyczne, 39 (1974), 3: 100-124.

Rørdam, Holger Frederik. Historieskriveren Arild Huitfeldt, Danmarks Riges Kansler og Raad, Skoleherre for Herlufsholm. Kjøbenhavn: V. Thaning \& Appel, 1896.

Rørdam, Holger F. [entry: Arild Huitfeldt]. In: Dansk biografisk Lexicon, ed. Carl Frederick Bricka, vol. 8. Kjøbenhavn: Gyldendalske Boghandels Forlag (F. Hegel \& Søn), 1894.

Szelągowska, Krystyna. “Arilda Huitfeldta szlachecka wizja dziejów narodowych Danii”. Roczniki Historyczne 86 (2020): 217-248.

Ślaski, Kazimierz. Tysiąclecie polsko-skandynawskich stosunków kulturalnych. Wrocław: Zakład Narodowy im. Ossolińskich, 1977. 
Śnieżko, Dariusz. “Jak Marcin Bielski przerabiał z dobrego na lepsze”. In: Tożsamość i rozdwojenie. Renesans. Materiały $z$ V sesji naukowej z cyklu "Świat jeden, ale nie jednolity”, ed. L. Wiśniewska, 211-220. Bydgoszcz: Akademia Bydgoska im. Kazimierza Wielkiego, 2002.

Woolf, Daniel R. The Idea of History in Early Stuart England, Erudition, Ideology and 'The Light of Truth' from the Accession of James I to the Civil War. Toronto: University of Toronto Press, 1990.

Wójcik, Zbigniew, ed. Historia dyplomacji polskiej. Vol. 2, Warszawa: PWN, 1982.

Wyczański, Andrzej. “Polska służba dyplomatyczna 1506-1530”. In: Polska służba dyplomatyczna XVI-XVIII wieku, ed. Zbigniew Wójcik, Warszawa: PWN, 1966.

Wyrozumski, Jerzy. Kazimierz Wielki. Wrocław: Ossolineum, 1982.

Wyrozumski, Jerzy. Dzieje Polski Piastowskiej (VIII wiek-1370), Wielka Historia Polski.

Vol. 2. Kraków: Wydawnictwo Pinnex, 1999.

Zins, Henryk. Polska w oczach Anglików. Warszawa: PIW, 1974.

\section{SUMMARY}

English version: Mark Atkinson

The enormous $16^{\text {th }}$ century book Chronicle of the Kingdom of Denmark, written in vernacular, is a testament to several features typical of that period's historiography. As a utilitarian history it was supposed to deliver moral and political lessons and arguments. It has a traditional form, in many parts annalistic. Despite several weaknesses, the work became very popular reading for generations of Danish nobility, influencing the development of historical consciousness. The Chronicle is also evidence of broadening the horizons of Danish elites, a group to which the author, the Chancellor of the Realm and the magnate, belonged. The paper presents information concerning Poland, included in the book. The fact that it was so could be simply a result of historical methods applied in this period (among others, copying and repeating sources), but it could be caused also by growing interests in Poland, seen as a partner in regional politics with the Baltic Sea as the centre. Some closer connections between Poland and Denmark, mainly in the $15^{\text {th }}$ and the $16^{\text {th }}$ centuries, could be connected with the network of conflicts and alliances among such political entities as: the Teutonic Order, the Holy Empire, Brandenburg, the Hanseatic League, Gdańsk and the whole of Pomerania. Most of the notes are scattered, rather short and do not create a comprehensive whole. In the case of more recent history, the narrative has a much more well-developed character (like for instance the case of the Thirteen Years' War). Some Polish context (probably fictitious) became useful when the author had to criticise King Christian II. Huitfeldt was also well-informed about the political system of the Commonwealth and included the information when writing about the Danish system, presenting both as similar. 


\section{Spojrzenie przez Bałtyk - Polska i jej dzieje w Kronice Królestwa Duńskiego Arilda Huifeldta}

Słowa kluczowe: Arild Huitfeldt, historiografia renesansowa, region bałtycki

\section{STRESZCZENIE}

XVI -wieczna Kronika Królestwa duńskiego, autorstwa Arilda Huitfeldta powstała na marginesie starań państwa o stworzenie nowoczesnej syntezy dziejów narodowych, mającej do spełnienia różnorakie polityczne cele, w odniesieniu do zagranicznego i krajowego odbiorcy. 9-tomowe dzieło omawia dzieje Danii od legendarnego króla Dana do roku 1559 (śmierć Chrystiana III). Napisane w języku narodowym, ma dość tradycyjną formę, bliską rocznikowi i kronice. Pozostaje historią pragmatyczną, realizującą polityczne, dydaktyczne i moralizatorskie cele. Mimo wielu słabości, historia ta przyniosła wizję dziejów Danii, kształtującą mentalność wielu pokoleń duńskich elit w epoce nowożytnej. Kronika jest świadectwem poszerzania się horyzontów elit duńskich tego czasu, które reprezentuje autor dzieła, magnat i kanclerz Korony, Arild Huitfeldt. Większe zainteresowanie Polską w tym kręgu mogło być skutkiem polsko-duńskich zbliżeń na tle skomplikowanego układu politycznego północnej Europy, splotu interesów i konfliktów (Polska - Dania - Szwecja - Zakon Krzyżacki Gdańsk - Hanza - Marchia Brandenburska - Cesarstwo). Celem artykułu jest ukazanie, jakie informacje o Polsce i jej dziejach znane były wykształconym elitom duńskim tego okresu. Tradycyjny kształt dzieła rzutuje na dobór przekazów, który cechuje przemieszanie informacji ważnych z błahymi. Informacje o Polsce w większości mają charakter rozproszonych wzmianek, dotyczących takich zdarzeń jak dynastyczne mariaże, dwustronne traktaty, wojny i bitwy oraz pojedyncze, czasem „sensacyjne” fakty. Narracja bardziej rozbudowana pojawia się w odniesieniu do nowszych dziejów, w przypadku m. in. wojny trzynastoletniej. Pewne polonicum, choć akurat nie związane z rzeczywistymi faktami, zostało użyte w krytyce króla Chrystiana II. Znający realia systemu politycznego Rzeczpospolitej kanclerz używał polskiego przykładu w opisie ustroju Danii, który uważał za podobny.

\section{Citation}

Szelągowska, Krystyna. "Casting a glance across Balticum - Poland and her past in Arild Huitfeldt's Chronicle". Studia Maritima XXXIV (2021): 61-86. DOI: 10.18276/sm.2021.34-03. 